\title{
EFFECT OF ACID DEPOSITION ON THE DISPLACEMENT OF AL(III) IN SOILS
}

\author{
DIETER RAAB ${ }^{1}$, AND WERNER STUMM ${ }^{2}$ \\ 1 Federal Institute for Water Resources and Water Pollution Control EAWAG \\ Ueberlandstrasse 133 \\ $2 \mathrm{CH}-8600$ Dübendorf \\ Federal Institute for Water Resources and Water Pollution Control EAWAG \\ Ueberlandstrasse 133 \\ $\mathrm{CH}-8600$ Dübendorf
}

\begin{abstract}
This study represents an assessment of some of the key factors influencing the mobility of $\mathrm{Al}(\mathrm{III})$ and its displacement in acid soils. This assessment is based on the effect of $\mathrm{pH}$ and other solution variables on the solubility of $\mathrm{Al}(\mathrm{III})$ and its complex formation with $\mathrm{OH}^{-}, \mathrm{F}^{-}$and organic ligands (fulvates and humates). Above all, the adsorption behavior of $\mathrm{Al}(\mathrm{III})$ on iron(III) (hydr)oxides and on $\mathrm{SiO}_{2}$ on one hand, and the adsorption of organic acids and of humic substances on mineral surfaces on the other hand was investigated. Adsorption is interpreted in terms of surface complex formation equilibria; the mass law constants derived permit the modeling of adsorption as a function of solution variables. It is illustrated that the distribution of oxides and hydroxides in the soil profile affects the $\mathrm{pH}$ buffering, determines the mobility of the organic acids while the mobility of Al(III) is primarily governed by the formation and dissolution of Al(III) (hydr)oxides.
\end{abstract}

\section{The Adsorption of Al(III) and of Organic Acids on Mineral Surfaces}

$\mathrm{Al}(\mathrm{III})$ is one of the main components of the earth crust. $\mathrm{Al}(\mathrm{III})$ is released to the environment as a consequence of the weathering of (congruent and incongruent dissolution) of Al bearing minerals (aluminum oxides and aluminum silicates). What is the mobility and the sink of the Al(III) incipiently released in the weathering process? We need to understand the adsorption behavior of $\mathrm{Al}$ (III) in order to assess its mobility in the environment, specifically in a soil column.

To study this adsorption behavior we choose as model adsorbents goethite ( $\alpha$-FeOOH) and amorphous $\mathrm{SiO}_{2}$ silica, (Aerosil, Degussa). The surfaces of these two minerals in the presence of waters are covered with functional hydroxo groups, $>\mathrm{OH}$, which - according to the surface complex formation model (Schindler and Stumm, 1987) - are able to interact chemically with $\mathrm{H}^{+}$, metal ions and ligands (anions or weak acids).

Surface charge. In the pH-range of interest in soils ( $\mathrm{pH} 4-7$ ) the surface of silica is negatively charged while that of goethite is positively charged. In acid-base titrations (Fig. 1) goethite has a zpc (zero point of charge) of ca. 8, while silica's $z p c$ is around $\mathrm{pH}=2-3$. The dependence of surface charge on $\mathrm{pH}$ as given in Figure 1 illustrates that the surface charge of $\mathrm{SiO}_{2}$ increases within the acid $\mathrm{pH}$ range only slightly with increasing $\mathrm{pH}$ (Schindler and Kamber, 1969), whereas the goethite surface shows a rather linear dependence of surface charge on $\mathrm{pH}$.

Water, Air, and Soil Pollution 68: 199-212, 1993.

(c) 1993 Kluwer Academic Publishers. Printed in the Netherlands. 
Fig.1 a

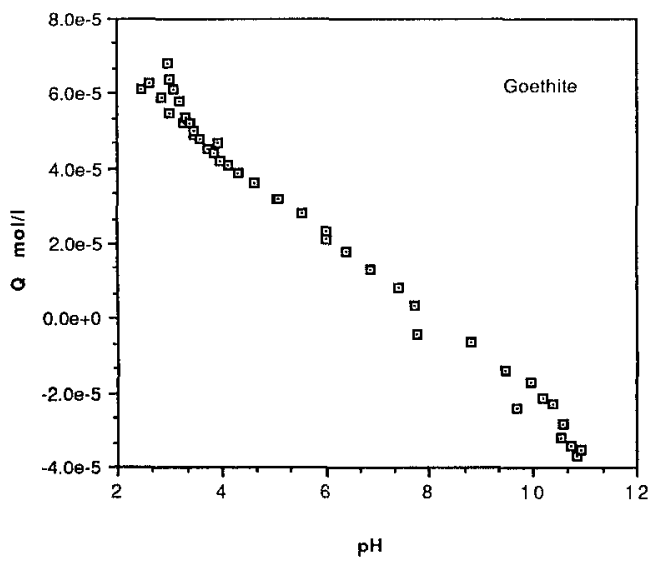

Fig.1b

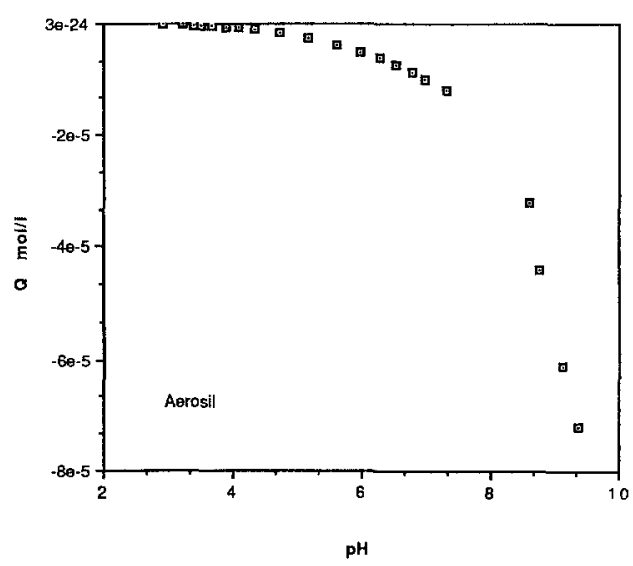

Fig. 1 Surface charge $Q$ of goethite $a$ and aerosil $b$ in $\mathrm{mol} / \mathrm{g}$ oxide vs. $\mathrm{pH}$.

Fig. $2 \mathrm{a}$

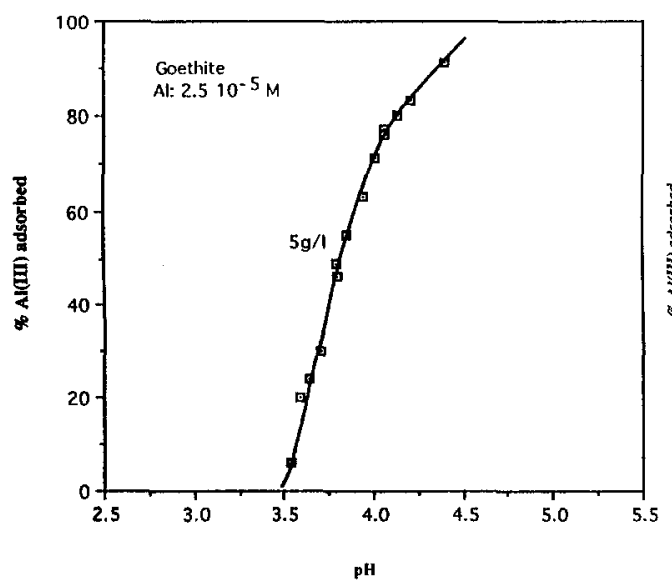

Fig 2b

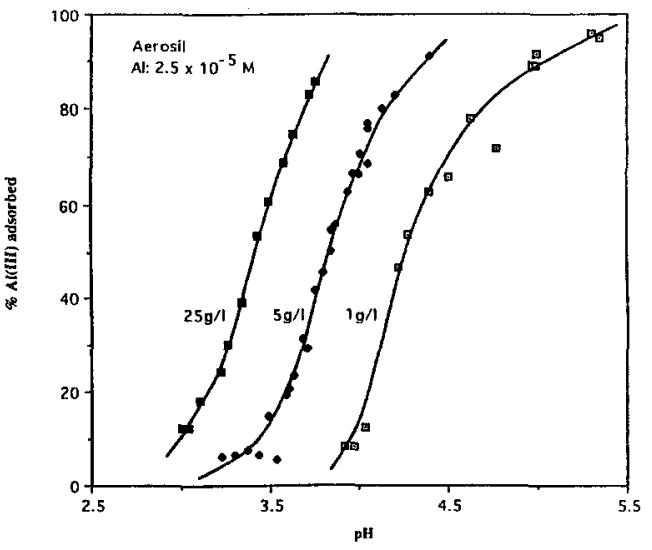

Fig. 2 Adsorption of aluminum out of a solution of $2.5 \times 10^{-5} \mathrm{~mol} / \mathrm{l}$ on goethite a and aerosil $\mathbf{b}$. For acrosil the suspension concentration was varied from 1 to $25 \mathrm{~g} / 1$ oxide.

Adsorption. Despite the marked difference in surface charge characteristics of these oxides, the extent of adsorption of $\mathrm{Al}$ (III) as a function of $\mathrm{pH}$ is very similar (Fig. 2). The fact that $\mathrm{Al}$ (III) is bound as strongly to the positively charged goethite surface as to the slightly negatively charged $\mathrm{SiO}_{2}$ surface indicates that the chemical interaction energy of the binding of $\mathrm{Al}^{3+}$ ions to the oxygen donor atoms of the functional $\mathrm{OH}$ groups outweighs the energy of electrostatic interaction. Obviously, Al(III) will, even at low $\mathrm{pH}$ - (the adsorption edge is around $\mathrm{pH}=3.5-4.3$ ) - become strongly sorbed to all mineral surfaces and, by implication, also to organic surfaces. Adsorption can be modeled with a set of equations for the acid base behavior of the oxide surface [1] - [2], and for mono- and bidentate aluminum surface complexes [3] - [4]. 


$\begin{array}{llll}>\mathrm{OH}_{2}^{+} & =>\mathrm{OH} & +\mathrm{H}^{+} & \mathrm{K}_{\mathrm{a} 1}^{\mathrm{s}} \\ >\mathrm{OH} & =>\mathrm{O}^{-} & +\mathrm{H}^{+} & \mathrm{K}_{\mathrm{a} 2}^{\mathrm{s}} \\ >\mathrm{OH}+\mathrm{Al}^{3+} & =>\mathrm{OAl}^{2+}+\mathrm{H}^{+} & \mathrm{K}_{1}^{\mathrm{s}} \\ 2>\mathrm{OH}+\mathrm{Al}^{3+} & =(>\mathrm{O})_{2} \mathrm{Al}^{+}+2 \mathrm{H}^{+} & \mathrm{\beta}_{2}^{\mathrm{s}}\end{array}$

As an alternative to $\mathrm{Eq}$ [4a] one could also write an equation characterizing the formation of a hydrolyzed adsorbed Al(III)

$$
>\mathrm{OH}+\mathrm{Al}^{3+}+\mathrm{H}_{2} \mathrm{O}=>\mathrm{OAl}-\mathrm{OH}^{+}+2 \mathrm{H}^{+} \quad \overline{\mathrm{K}}_{1}^{\mathrm{s}}
$$

TABLE 1 Properies of minerals used

\begin{tabular}{|c|c|c|c|c|}
\hline & Aerosil $0 \times 50$ & Aluminum oxide & Goethite & units \\
\hline Surface area ${ }^{1)}$ & so & 110 & 24 & $\frac{\mathrm{m}^{2}}{\mathrm{~g}}$ \\
\hline Exchange capacity ${ }^{2)}$ & $9 \mathrm{E}-5$ & $2.5 \mathrm{E}-4$ & $6.5 \mathrm{E}-5$ & $\frac{\mathrm{mol}}{\mathrm{g}}$ \\
\hline Inner layer capacity & 1 & & 0.9 & $\frac{F}{m^{2}}$ \\
\hline $\log \mathrm{Ka}_{1}^{5}$ (intr. $)^{3)}$ & - & & 7.1 & \\
\hline $\log \mathrm{Ka}_{2}^{\mathrm{s}}$ (intr.) ${ }^{3)}$ & 6.5 & & 9.3 & \\
\hline
\end{tabular}

1) by BET

2) determined experimentally by adding excess of acid to the hydrous oxide and backtitrating supernatant

3) determined experimentally for aerosil; values for goethite from Sigg and Stumm (1981)

Table 1 Speciation of used oxides.

Aerosil $0 \times 50$ a Degussa silica product.

Aluminum oxide from Degussa and goethite from Wards.

TABLE 2 Adsorption constanis ${ }^{1)}$ of aluminium on aerosil $0 \times 50$ and goethite

\begin{tabular}{|c|c|c|}
\hline & Aerosil $0 \times 50$ & Goethite \\
\hline $5 \mathrm{~g} / \mathrm{l}$ suspension & & \\
\hline $\log \mathrm{K}_{1}^{5}$ & -1.30 & -0.4 \\
\hline $\log \beta_{2}^{\mathrm{s}}$ & -0.96 & 0.22 \\
\hline $25 \mathrm{~g} / \mathrm{l}$ suspension & & \\
\hline $\log \mathrm{K}_{1}^{5}$ & -1.65 & - \\
\hline $\log \beta_{2}^{s}$ & -1.40 & - \\
\hline
\end{tabular}

1) Constants, as defined in Eqs [3] and [4a]; for methods of determination see Raab (1989).

Table 2 Adsorption constants calculated with help of equation 1-4 for the aluminum adsorption data.

TABLE 3 Adsorption constants ${ }^{1)}$ for the adsorption of phthatic acid on goethite and oxalic acid on aluminium oxide and acidity constants

\begin{tabular}{|l|c|c|c|c|}
\hline & $\log \mathrm{K}_{1}^{\mathrm{s}}$ & $\log \mathrm{K}_{2}^{\mathrm{s}}$ & $\mathrm{pK}_{\mathrm{a} 1}$ & $\mathrm{pK}_{\mathrm{a} 2}$ \\
\hline Phthalic acid & 7.30 & 2.40 & 2.80 & 4.90 \\
\hline Oxalic acid & 11.50 & 16.50 & 1.26 & 3.80 \\
\hline
\end{tabular}

1) Constants, as defined in Eqs [7] and [8], respectively; for methods of determination see Raab (1989).

Table 3 Adsorption constants for the adsorption of phthalic acid on goethite and oxalic acid on aluminum oxide calculated with the help of equation 7-11. 
In reaction [4a] and [4b] two protons are released per metal ion sorbed; Dzombak and Morel (1990) have shown that it is difficult to distinguish experimentally between [4a] and [4b]; usually data can be fitted equally well by both equations. We have chosen Eq 4a to represent the adsorption equilibrium. A detailed analysis of the experimental result (Raab, 1989) indicates that the extent of formation of the mononuclear complex (cf Eq [3]) is small in comparison to the formation of the bidentate (Eq 4a) (Table 2). Data were fitted with the help of an equilibrium model using total concentrations and Eqs [1] - [4a] (MICROQL version adapted for personal computers). The results are also compatible with an experimental assessment of the protons released per Al(III) bound to the surface (Honeyman and Leckie, 1986). In the Kurbatov plot, based on the most general equation,

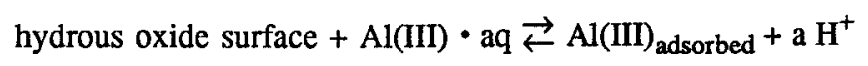

$\log \left[\mathrm{Al}(\mathrm{III})_{\text {adsorbed }}\right] /[\mathrm{Al}(\mathrm{III})(\mathrm{aq})]$ is plotted vs $\mathrm{pH}$. The number $\mathrm{H}^{+}$produced per $\mathrm{Al}$ adsorbed is given by a if the hydrous oxide surface is in excess (and constant).

Experimentally we found a value of $\mathrm{a}=2.3$ which is larger than expected but tends to support the preponderance of reaction [4a] or [4b].

Adsorption of Organic Acids on Mineral Surfaces. For soil scientists podzol formation is strongly related to the fate of organic acids and especially of fulvic acids in soils. Therefore two categories of organic acids were used in this study. First low molecular weight organic acids like salicylate, oxalate, phthalate which represent root exudates and second a technical fulvic acid product (Fluka) as a representative of the dominating humic matter fraction in acid soils.

The adsorption behavior of the low molecular weight organic acids (Fig. 3) can be described by the interaction of the metal centers with the acid functional groups (ligand exchange) (Kummert and Stumm, 1980). Although the correct steric configuration of the

Fig.3 a

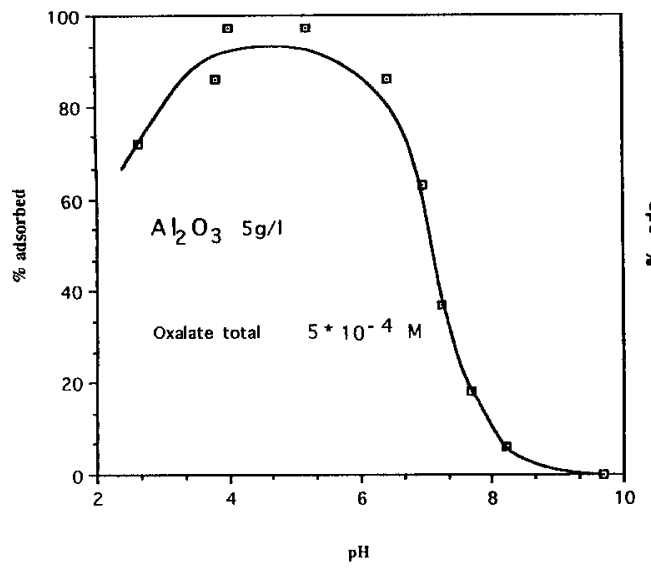

Fig. 3 b

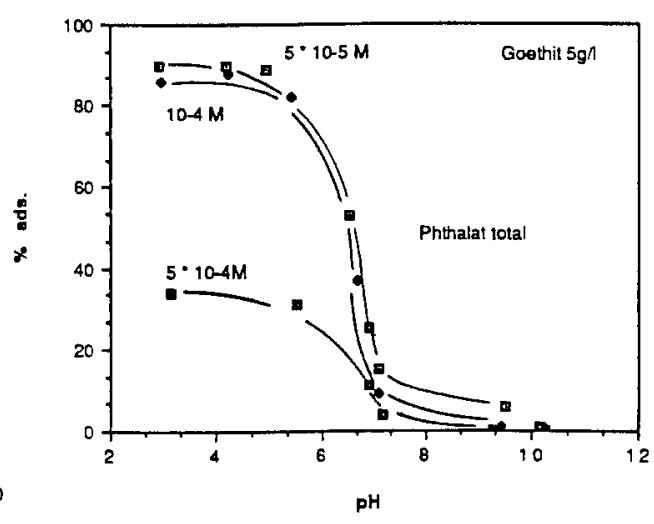

Fig. 3a and b (a) Adsorption of oxalate out of a solution of $5 \times 10^{-4} \mathrm{~mol} / 1 \mathrm{on} 5 \mathrm{~g} / \mathrm{l}$ aluminium oxide. (b) Adsorption of varying phthalate concentrations on $5 \mathrm{~g} / 1$ goethite. 
organic surface complexes is only in a few case studies unequivocally determined (Motschi and Rudin, 1984) there is a lot of evidence coming from mineral dissolution studies (Stumm and Furrer, 1987) which clearly show inner-sphere character of the adsorbed organic acids. Stability constants for the surface complexes were determined (Table 3 ) by the use of equilibria for the reactions given below. (The method described by Kummert and Stumm, 1980, was used.)

TABLE 4 A comparison of the main proton sources and sinks in soils

\begin{tabular}{|c|c|l|}
\hline & $\begin{array}{c}\text { Rate in keq/ha } \\
\mathrm{yr}^{-1}\end{array}$ & \multicolumn{1}{|c|}{ Reference } \\
\hline Acid load from the atmosphere & & \\
\hline prehistoric & 0.2 & Ulrich et al., 1979 \\
\hline today in central Europe & $1-3$ & Ulrich, 1986 \\
\hline $\begin{array}{c}\text { Acid load due to the transformation of organic } \\
\text { material in soils }\end{array}$ & & \\
\hline nitrification & -4 & Ulrich, 1986 \\
\hline $\mathrm{CO}_{2}$ production & -15 & van Breemen et al.,1983 \\
\hline Proton sinks in soils due to mineral dissolution & & \\
\hline acidic forest soil & $0.7-1.3$ & Ulrich, 1979 \\
\hline acidic forest soil & 2.2 & van Breemen et al., 1983 \\
\hline on calcareous soils & -15 & van Breemen et al., 1983 \\
\hline
\end{tabular}

Table 4 A comparison of the main proton sources and sinks in soils.

The organic acids used have two functional groups and are able to form surface chelates such as

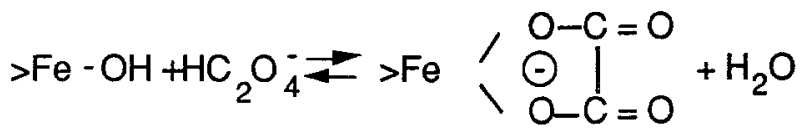

mass law equations can be formulated for the reactions ( $\mathrm{L}$ is the ligand)

$$
\begin{array}{lll}
>\mathrm{FeOH}+\mathrm{L}^{2-}+2 \mathrm{H}^{+} & =>\mathrm{FeLH}+2 \mathrm{H}_{2} \mathrm{O} & \mathrm{K}_{1}^{\mathrm{s}} \\
>\mathrm{FeOH}+\mathrm{L}^{2-}+\mathrm{H}^{+} & =>\mathrm{FeL}^{-}+\mathrm{H}_{2} \mathrm{O} & \mathrm{K}_{2}^{\mathrm{s}} \\
>\mathrm{FeOH}_{2}^{+}+\mathrm{H}^{+} & =>\mathrm{FeOH}+\mathrm{H}^{+} & \mathrm{K}_{\mathrm{a} 1}^{\mathrm{s}} \\
>\mathrm{FeOH} & =>\mathrm{FeO}^{-}+\mathrm{H}^{+} & \mathrm{K}_{\mathrm{a} 2}^{\mathrm{s}} \\
\mathrm{L}^{2-}+\mathrm{H}^{+} & =\mathrm{HL}^{-} & \mathrm{K}_{\mathrm{a} 2} \\
\mathrm{~L}^{2-}+2 \mathrm{H}^{+} & =\mathrm{H}_{2} \mathrm{~L} & \mathrm{~K}_{\mathrm{a} 2} \cdot \mathrm{K}_{\mathrm{a} 1}
\end{array}
$$


The carboxylic acids used are sorbed rather strongly on the goethite and aluminum-oxide surface; they are not bound in the pH-range of interest to the silica surface. Obviously, the interaction is by ligand exchange; the carboxylates are known to form complexes with Fe(III) atoms in the surface layer of the goethite. Si(IV) is not able to form stable complexes with organic acids. The pH dependence of the specific adsorption can be quantitatively accounted for by the mass law equations given above. The adsorption maximum observed near the $\mathrm{pK}_{\mathrm{a}}$ value of the conjugate acid of the ligand is fully explainable by mass law considerations (Stumm, 1992).

Humic substances. The adsorption behavior of humic substances is more complicated than that of low molecular acids because the extent of adsorption depends not only on the energy of the coordinative interaction, and the energy of electrostatic interaction but can also be influenced by the hydrophobic effect. Humic substances contain in addition to the hydrophilic hydroxo and carboxyl groups hydrophobic moieties (fatty acid chains) which tend to be expelled from the water phase.

Fig. 4 a

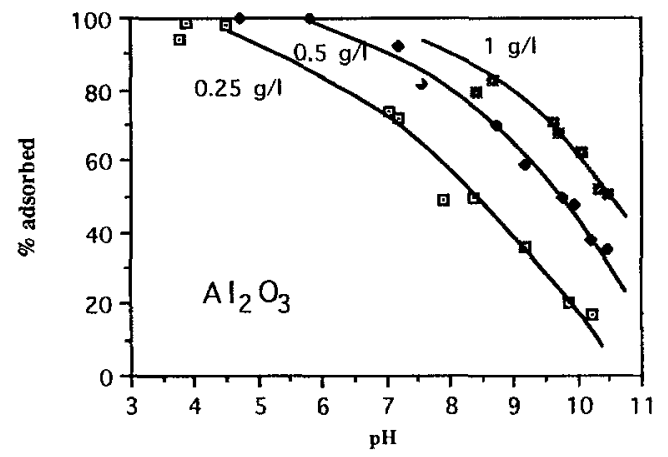

Fig. 4 b

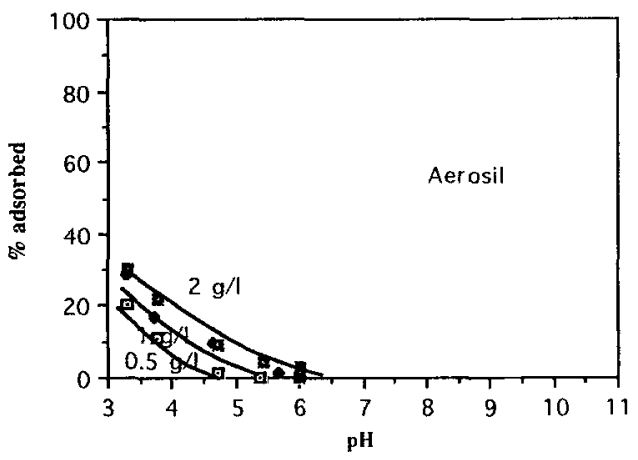

Fig. 4a and b (a) Adsorption of humic substance $10.2 \mathrm{mg} / 1 \mathrm{DOC}$ on varying suspension concentrations of aluminum oxide in the range $0.25-1 \mathrm{~g} / \mathrm{l}$. The humic substance used is a fulvic acid («Fluka») with a molecular weight between 600-1000. (b) The same as under a) but adsorption on aerosil.

Fig. 4 gives experimental results of the adsorption of fulvic acid (Fluka) on $\mathrm{Al}_{2} \mathrm{O}_{3}$ and $\mathrm{SiO}_{2}$. While adsorption on $\mathrm{SiO}_{2}$ is negligible in the $\mathrm{pH}$ range of interest, fulvic acids show a strong tendency to become adsorbed on $\mathrm{Al}_{2} \mathrm{O}_{3}$ surfaces: the pH dependence of adsorption is similar to that of the low molecular weight organic acids; it is reasonable to imply that coordinative interactions (ligand exchange) (the binding of the carboxylates to the Lewis acid Al(III) centers exceeds the binding to Si(IV)) dominate the adsorption of fulvic acids. This is also evident by the fact that the negatively charged fulvic acid anions adsorb at $\mathrm{Al}_{2} \mathrm{O}_{3}$ even at $\mathrm{pH}$ values above 8 where the $\mathrm{Al}_{2} \mathrm{O}_{3}$ surface is negatively charged.

Complex formation of aluminum with organic and inorganic ligands in the soil solution. For a principal insight in the aluminum complex formation ability the aluminum humic acid complex formation model of Lövgren et al. (1987) was used and compared with the aluminum fluoro and sulfato formation*. The Lovgren model describes the Al-humic complex formation with two acidity constants and three aluminum complexes Eq [13] - [17]. 


$\begin{array}{llrl}\mathrm{H}_{2} \mathrm{~L} & =\mathrm{HL}^{-}+\mathrm{H}^{+} & \mathrm{pK}_{\mathrm{a} 1}=3.4 \\ \mathrm{HL}^{-} & =\mathrm{L}^{2-}+\mathrm{H}^{+} & \mathrm{pK}_{\mathrm{a} 2}=4.9 \\ \mathrm{Al}^{3+}+\mathrm{H}_{2} \mathrm{~L} & =\mathrm{AIL}^{+}+2 \mathrm{H}^{+} & \log \beta_{1}=-4.0 \\ \mathrm{Al}^{3+}+2 \mathrm{H}_{2} \mathrm{~L} & =\mathrm{AIL}_{2}^{-}+4 \mathrm{H}^{+} & \log \beta_{2}=-7.75 \\ \mathrm{Al}^{3+}+\mathrm{H}_{2} \mathrm{~L} & =\mathrm{AL}\left(\mathrm{H}_{-1}\right) \mathrm{L}+3 \mathrm{H}^{+} & & \log \beta_{3}=-8.15\end{array}$

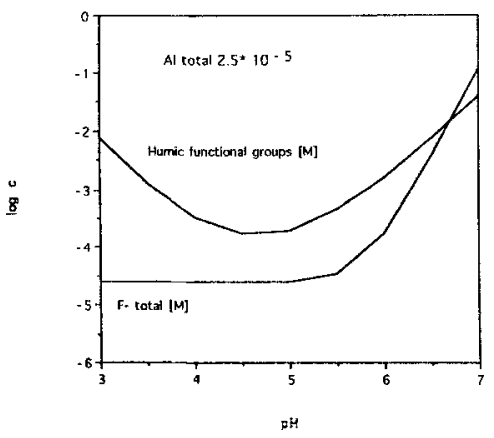

Fig. 5 Estimate of the necessary humic and fluoride concentrations to complex $2.5 \times 10^{-5} \mathrm{~mol} / \mathrm{l}$ aluminum.

The constants given are from Lövgren et al. (1987). The relative importance of the different ligands and species (AlF, AlHumic, $\mathrm{Al}(\mathrm{OH})_{1-4}, \mathrm{Al}^{3+}$ ) is calculated in Fig. 5 for a fixed aluminum concentration typical for soil solutions. The ordinates of Fig. 5 represent total ligand concentrations humic acid and $\mathrm{F}^{-}$which are necessary to complex aluminum to the same amount as water itself. So this figure can be used to estimate for a given $\mathrm{pH}$ and ligand concentration the importance of this ligand for the aluminum speciation.

Humic acids have their strongest complexation ability for aluminum in the $\mathrm{pH}$ range between $\mathrm{pH} 4.5-5$. Below $\mathrm{pH} 4$ the functional groups of humic acids interact preferably with protons; above $\mathrm{pH} 5 \mathrm{Al}(\mathrm{III})$ tends to bind $\mathrm{OH}^{-}$rather than humate so that higher concentrations of humic acids are necessary to complex $\mathrm{Al}$ (III). For fluoride the situation is somewhat different, because $\mathrm{F}^{-}$becomes only protonated below $\mathrm{pH}=3$. To complex most of $\mathrm{Al}$ (III) present at $\mathrm{pH}<5$ would require ca. $2.5 \times 10^{-5} \mathrm{MF}^{-}$i.e., a concentration that is higher than that typically present in soil waters; at $\mathrm{pH}$ values higher than $\mathrm{pH} 5$, hydroxo complex formation of Al(III) would - similarly as with humic acids - outcompete fluoro complex formation.

Thus, one can generalize that the speciation of $\mathrm{Al}(\mathrm{III})$ is dominated at $\mathrm{pH}<4.5$ by free $\mathrm{Al}^{3+}$; at $\mathrm{pH}>5.5$ hydroxo $\mathrm{Al}(\mathrm{III})$ complexes predominate. Only in the critical $\mathrm{pH}$ range $4.5-$ 5.5 complexes of Al(III) with humate functional groups and with fluoride play a major role in the speciation of $\mathrm{Al}(\mathrm{III})$.

* Aluminum sulfate complex formation is not able to compete under realistic soil solution concentration for sulfate in the range of $10^{-5}-10^{-4} \mathrm{M}$. 


\section{Acid and Base Neutralizing Capacities in Soils, Buffering and Mineral Dissolution}

An assessment on the effects of acid deposition on soils requires identification of the various proton producing and proton consuming processes and consideration of the buffering factors, involved in the impact of atmospheric depositions (acid rains) and in the acid and base neutralizing interactions of minerals, of biota, of humus and of various redox processes.

Biomass tumover in soils, above all nitrogen cycling is - in addition to acid deposition of utmost importance as a proton source (Ulrich, 1986; Schnoor and Stumm, 1985).

In a most general way the synthesis (assimilation) and the decomposition (respiration) of biomass can be written stoichiometrically as

$$
\begin{aligned}
& \text { a } \mathrm{CO}_{2}(\mathrm{~g})+\mathrm{b} \mathrm{NO}-\mathrm{c} \mathrm{HPO}_{4}^{2-}+\mathrm{d} \mathrm{SO}_{4}^{2-}+\mathrm{g} \mathrm{Ca}^{2+}+\mathrm{h} \mathrm{Mg}^{2+} \\
& +\mathrm{i} \mathrm{K}^{+}+\mathrm{f} \mathrm{Na}^{+}+\mathrm{xH}_{2} \mathrm{O}+(\mathrm{b}+2 \mathrm{c}+2 \mathrm{~d}-2 \mathrm{~g}-2 \mathrm{~h}-\mathrm{i}-\mathrm{f}) \mathrm{H}^{+} \\
& \stackrel{\mathrm{L}}{\rightleftarrows}\left\{\mathrm{C}_{\mathrm{a}} \mathrm{N}_{\mathrm{b}} \mathrm{P}_{\mathrm{c}} \mathrm{S}_{\mathrm{d}} \ldots \mathrm{Ca}_{\mathrm{gMg}} \mathrm{K}_{\mathrm{i}} \mathrm{Na}_{\mathrm{f}} \mathrm{H}_{2} \mathrm{O}_{\mathrm{m}}\right\}_{\text {biomass }}+(\mathrm{a}+2 \mathrm{~b}) \mathrm{O}_{2}
\end{aligned}
$$

Using a general definition for alkalinity ${ }^{* *}$ whereby any decrease (increase) in concentrations of base cations (e.g., $\mathrm{K}^{+}, \mathrm{Ca}^{2+}, \mathrm{Fe}^{2^{+}}$etc.) or any increase (decrease) in concentrations of «acid anions» (e.g., $\mathrm{NO}_{3}^{-}, \mathrm{HPO}_{4}^{2-}, \mathrm{SO}_{4}^{2-}$ etc.) is accompanied by a decrease (increase) in alkalinity (Stumm and Morgan, 1981). Thus, the net synthesis of terrestrial biomass (e.g., on the forest and forest floor, where more cations than anions are taken up by the plants (trees)), is accompanied by a release of $\mathrm{H}^{+}$to the environment. The acidification of the environment is accompanied by an increase in base in the aggrading biomass (wood and vegetation). The ash of wood and of vegetation is alkaline; one speaks of "potash". Oxidative decomposition of biota is a potential proton sink for soils. Nitrification and denitrification are also key reactions in the production and consumption of $\mathrm{H}^{+}$, i.e. in the decrease and increase in alkalinity:

$$
\begin{aligned}
& \mathrm{NH}_{3}+2 \mathrm{O}_{2} \rightleftarrows \mathrm{NO}_{3}^{-}+\mathrm{H}^{+}+\mathrm{H}_{2} \mathrm{O} \\
& \mathrm{NH}_{4}^{+}+2 \mathrm{O}_{2} \rightleftarrows \mathrm{NO}_{3}^{-}+2 \mathrm{H}^{+}+\mathrm{H}_{2} \mathrm{O} \\
& 1 \frac{1}{4} \mathrm{CH}_{2} \mathrm{O}+\mathrm{NO}_{3}^{-}+\mathrm{H}^{+} \longrightarrow 1 \frac{1}{4} \mathrm{CO}_{2}+\frac{1}{2} \mathrm{~N}_{2}+1 \frac{3}{4} \mathrm{H}_{2} \mathrm{O}
\end{aligned}
$$

The dissolution of minerals of carbonates, (hydr)oxides of $\mathrm{Al}(\mathrm{III})$ and $\mathrm{Fe}$ (III) and of aluminum silicates are important $\mathrm{H}^{+}$ion consuming processes in the delicate proton balance of soil solutions.

$$
\begin{aligned}
& \mathrm{CaCO}_{3}(\mathrm{~s})+\mathrm{H}^{+} \underset{\mathrm{Ca}^{2+}}{\rightleftarrows} \mathrm{HCO}_{3}^{-} \\
& \mathrm{Al}(\mathrm{OH})_{3}(\mathrm{~s})+3 \mathrm{H}^{+} \rightleftarrows \mathrm{Al}^{3+}+3 \mathrm{H}_{2} \mathrm{O}
\end{aligned}
$$

If the weathering rate equals or exceeds the rate of $\mathrm{H}^{+}$release by the biota, such as would be the case in a calcareous soil, the soil will maintain a buffer in base cations and residual alkalinity. On the other hand, in noncalcareous "acid" soils, the rate of $\mathrm{H}^{+}$release by the biomass may exceed the rate of $\mathrm{H}^{+}$consumption by weathering and causes a progressive acidification of the soil. In some instances, the acidic atmospheric deposition may be

** Alkalinity [Alk] or acid neutralizing capacity is defined as

$[\mathrm{Alk}]=\left[\mathrm{HCO}_{3}^{-}\right]+2\left[\mathrm{CO}_{3}^{2}\right]+\left[\mathrm{OH}^{-}\right]-\left[\mathrm{H}^{+}\right]$.

Considering a charge balance of a typical soil water one realizes that [Alk] can also be expressed by a charge balance - the equivalent sum of conservative cations $\left(\mathrm{K}^{+}, \mathrm{Ca}^{2+}\right.$ etc.) less the sum of conservative anions $\left(\mathrm{Cl}^{-}, \mathrm{SO}_{4}^{2-}\right.$ etc. $)$. 
biomass may exceed the rate of $\mathrm{H}^{+}$consumption by weathering and causes a progressive acidification of the soil. In some instances, the acidic atmospheric deposition may be sufficient to disturb an existing $\mathrm{H}^{+}$balance. A quantitative example is provided by the carefully established acidity budget in the Hubbard Brook Ecosystem, (Driscoll and Likens, 1982). Ion exchange processes of soil minerals and of humus represents an intermediate buffering pool of fast exchangeable bases.

The large pool of mineral bases is characterized by relatively slow kinetics of chemical weathering. Rates of weathering of oxides and silicates are $\left[\mathrm{H}^{+}\right]$dependent, surface controlled reactions (Furrer and Stumm, 1986; Stumm and Wollast, 1990; Stumm and Wieland, 1990). It was also shown by these authors that complex forming ligands like oxalate, salicylate, citrate etc. enhance the rate of the dissolution. It has to be recognized that soil solution buffering due to mineral dissolution is strongly depending on the mineral surface supply. This supports the outstanding role of oxides for solution buffering. They exhibit a much higher surface area in acid soils than feldspar and are even more easily dissolvable than clays (Stumm and Wieland, 1990). The effect of fulvic and humic acids on accelerating or inhibiting the dissolution of minerals is not yet established.

\section{An Acidic Soil System and the Interaction of the Processes}

The ideas presented on the adsorption of aluminum and organic acids, on solution complexation and mineral dissolution have to be compared with the limitations given by the soil system itself. Acid load, buffering-rates, mineral assembly, surface supply, ligand distribution have to be estimated in their relevance for affecting the $\mathrm{H}^{+}$ion balance in soils.

The Mineral Assembly in Acidic Soils. Acidic soils are depleted of carbonate bearing minerals. Silicates are predominantly quartz, clays and feldspars. Oxides and hydroxides are ferrihydrite for iron and aluminum hydroxides, or the most simple aluminum silicates, socalled allophanes. The vertical distribution in the soil profile reflects the acid attack and aluminum mobility. The upper soil parts consist almost exclusively of quartz which has little influence on soil $\mathrm{pH}$ and aluminum mobility. In podzolic soils at a discrete front, iron(oxides) hydroxides and somewhat further downward aluminum(oxides) hydroxides are present in the profile. The iron(oxides) hydroxides are forming discrete mineral phases while aluminum(oxides) hydroxides are dispersely distributed and may be coating other mineral surfaces (Giovanoli et al., 1988). The acidic soil solution is neutralized in contact with the oxides and causes the low $\mathrm{pH}$ in the upper soil parts to rise by about $1-1.5 \mathrm{pH}$ units as soon as oxides are present.

The Organic Matter in Acidic Soils. Organic matter is typically enriched at the top of acidic soils due to the low $\mathrm{pH}$ and related reduced bacterial activity so that often primarily fungi are involved in the slow mineralization of the organic material to form humus and humic acids. At deeper parts of acidic soils the appearance of humic material is related to the occurrence of oxides and can lead to a distinct organic rich layers in the lower soil profile. Oxides force the organic acids to adsorb as shown in Figs. 3 and 4. The DOC of the soil solution as an indicator for the aluminum complexing organic acids varies in relation to soil solution $\mathrm{pH}$ and oxide-hydroxide distribution. In the upper humic material rich and acidic soil parts dissolved organic material can reach concentrations in the range of up to $30 \mathrm{mg} / \mathrm{LOC}$. In the lower soil parts in the presence of oxides and hydroxides and under elevated $\mathrm{pH}$ values the 
dissolved organic carbon in the soil solution is reduced by more than one order of magnitude to about $1-3 \mathrm{mg} / 1$ DOC (McDowell and Wood, 1984).

Aluminum Species Distribution in the Soil Solution. One can distinguish two typical situations for aluminum species in acidic soils.

1. At low $\mathrm{pH}$, (i.e., ca. $\mathrm{pH}<5$ ), high aluminum concentrations, high $\mathrm{DOC}$ and fluoride concentrations typical for situations in the upper soil or under macro pore water flow.

2. At less acidic pH-values ( $\mathrm{pH}$ 5-7), low aluminum concentration, low DOC and fluoride concentrations in the deeper soil parts.

In the first case one can use a total aluminum concentration of $2.510^{-5}$ molar which reflects aluminum hydroxide solubility below pH $4.3\left(\mathrm{~K}_{\mathrm{s} 0}=10^{-33.5}\right)$. DOC reaches values of around $30 \mathrm{mg} / \mathrm{l}$ and can be translated in a ligand concentration of around $3 \cdot 10^{-4} \mathrm{M}$ if one assumes the carbon content of humic or fulvic acids of about $50 \%$ and a typical functionality of $10 \mathrm{mmol} / \mathrm{g}$ humic acid (Perdue, 1985). The acid functional groups are only partly involved in metal complexation, so Lövgren et al. postulated that only half of the acid functional groups are involved in aluminum complexation. Fluoride concentration was considered to be in maximum $5 \mu \mathrm{mol} / \mathrm{A}$ (Johnson et al., 1981). The species distribution can be seen in Fig. 6. Humic acids would strongly influence aluminum complexation in an intermediate $\mathrm{pH}$ range (4.5 - 5.5); but only free $\mathrm{Al}^{3+}$ has to be considered in the upper soil parts under strong acidic conditions with $\mathrm{pH}$ values between $3-4$.

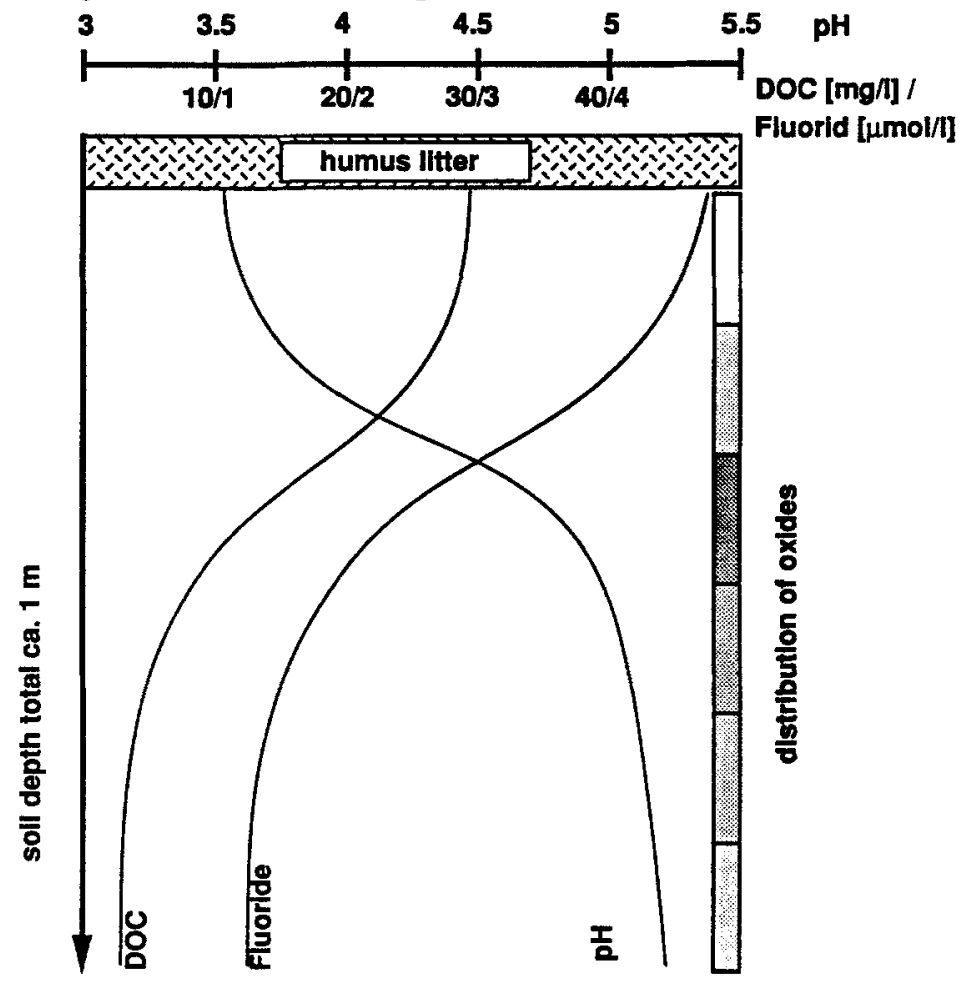

Fig. 6 Aluminum speciation representative for upper (acidic) soil parts. Assumed aluminum concentration $2.5 \times 10^{-5} \mathrm{M}$, fluoride concentration $5 \times 10^{-6} \mathrm{M}$, humic acid concentration $3 \times 0^{-4} \mathrm{M}$ which correspond to ca. $30 \mathrm{mg} / 1 \mathrm{DOC}$. 


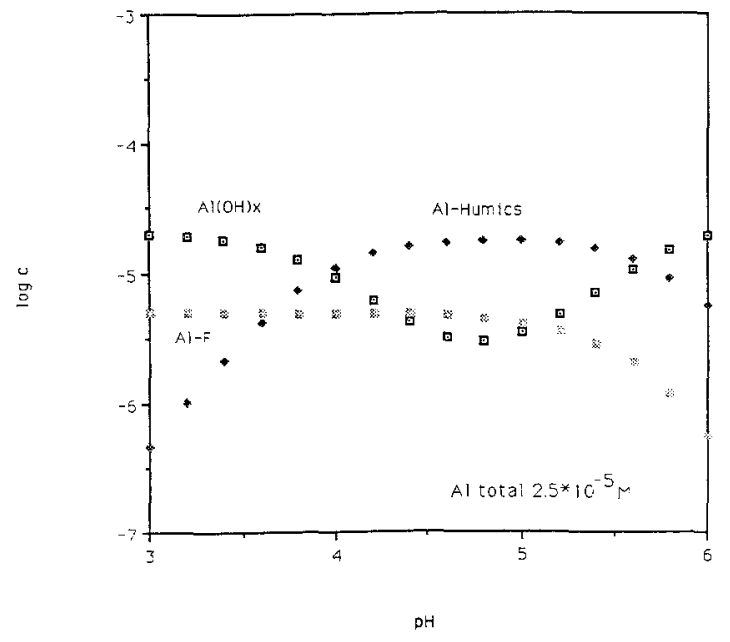

Fig. 7 Aluminum speciation representative for a deeper (acidic) soil profile. Assumed aluminum concentration $2.5 \times 10^{-6} \mathrm{M}$, fluoride concentration $1 \times 10^{-6} \mathrm{M}$, humic acid concentration $15 \times 10^{-5} \mathrm{M}$ which correspond to ca. $1.5 \mathrm{mg} / \mathrm{l}$ DOC.

The second case should reflect the species distribution under higher $\mathrm{pH}$ conditions in the deeper soil part and in presence of oxides and hydroxides of iron and aluminum. The aluminum concentration would be reduced by a factor of 10 to ca. $2.5 \cdot 10^{-6}$ molar as a consequence of adsorption and precipitation re-actions. Dissolved organic matter will be reduced from soil solution to around $1-3 \mathrm{mg} /$, thus we calculate a total functionality of around $1.5 \cdot 10^{-5}$ molar organic ligand groups. Parallel to the disappearance of organic acids out of the soil solution due to adsorption on oxide surfaces, the concentration of fluoride is expected to be reduced too. Fluoride shows a strong affinity to oxide surfaces (Sigg and Stumm, 1981) in the near neutral $\mathrm{pH}$ range. The fluoride concentration can be estimated to lie in the order of around $1 \mu$ molar. The species distribution is shown in Fig. 7. Free aluminum and hydroxo aluminum species prevail at $\mathrm{pH} 5$. Fluoride and humic acids would influence the species distribution with increasing concentrations but under the conditions chosen play a minor role.

\section{Interaction of the Processes and Conclusion}

Soil acidification is primarily caused by the low buffer capacity of the soil. The delicate $\left[\mathrm{H}^{+}\right]$balance between $\mathrm{H}^{+}$production due to release of $\mathrm{H}^{+}$by roots and by consumption of $\mathrm{H}^{+}$by weathering is distributed by active depositions and microbially mediated redox processes. The decrease in $\mathrm{pH}$ in turn mitigates biodegradation of plant litter and favors the production of fulvic acid. The fulvic acids pass through the bleached layers of the upper soil, because the tendency for surface complexation is weak because of the low $\mathrm{pH}$. Al(III) preponderantly present as free $\mathrm{Al}^{3+}$ or in presence of $\mathrm{F}^{-}$as fluor complexes is displaced into the lower layers. Further downward, the presence of aluminum (hydr)oxides causes the consumption of $\mathrm{H}^{+}$ion resulting in a $\mathrm{pH}$-increase of at least one $\mathrm{pH}$ unit, and, in turn, the adsorption (specific binding) of the organic ligands, residual $\mathrm{Al}(\mathrm{III})$ is present primarily as inorganic complexes (hydroxo, fluoro). 
The distribution in the soil profile of oxides and hydroxides reflects the pH-buffering and determines the mobility of organic acids. The mobility of $\mathrm{Al}$ (III) is governed by the formation and dissolution of $\mathrm{Al}$ (III) (hydr)oxides. If an acid pulse causes the complete dissolution of the $\mathrm{Al}(\mathrm{III})$ (hydr)oxides, $\mathrm{pH}$-buffering breaks down, $\mathrm{pH}$ decreases and organic acids are displaced further downward.

\section{Acknowledgements}

This research was supported by the Swiss Federal Institute of Technology Zürich (ETHZ)

(Project $\mathrm{WaBoLu})$. Two anonymous reviewers were very helpful in improving the manuscript. 


\section{References}

Cozarelli, I.M., Herman, J.S., and Parnell, R.A. Jr. The mobilization of aluminum in a natural soil system: effects of hydrological pathways. Water Resources Research 23/5, 859-874 (1987).

Driscoll, C. T. and Likens G. E. Hydrogen ion budget of an aggrading forested ecosystem. Tellus 34, 283-292 (1982).

Dzombak, D.A. and Morel, F.M.M. Surface Complexation Modeling, Hydrous Ferric Oxide; Wiley-Interscience, New York (1990).

Furrer, G. and Stumm W. The coordination chemistry of weathering: I. Dissolution kinetics $\delta$ $\mathrm{Al}_{2} \mathrm{O}_{3}$ and $\mathrm{BeO}$. Geochim. \& Cosmochim. Acta 50, 1847-1860 (1986).

Giovanoli, R.; Schnoor J.L.; Sigg, L.; Stumm W.; Zobrist J. Chemical weathering of crystalline rocks in the catchment area of acidic ticino lakes, Switzerland. Clay and Clay Minerals 36, 6, 521-529 (1988).

Honeymann, B.O. and Leckie, J.O. An experimental and mathematical investigation of cation and anion adsorption in binary mixtures of adsorbents. Workshop on Aquatic Surface Chemistry, Wolfsberg Conference Center (1986).

Johnson, N.M.; Driscoll, C.T. ; Eaton J.S.; Likens G.E.; McDowell W.H. Acid rain. Dissolved aluminum and chemical weathering at the Hubbard Brook Experimental Fores. Geochim Cosmochim. Acta 46, 1421-1453 (1981).

Kummert, R. and Stumm, W. The surface complexation of organic acids on hydrous $\gamma-\mathrm{Al}_{2} \mathrm{O}_{3}$. J. Colloid \& Interface Sci. 75, 373-385 (1980).

Lövgren, L., Hedlund, T., Öhman, L.O., and Sjöberg, S. Equilibrium approaches to natural water systems - 6. Acid-base properties of a concentrated bog-water and its complexation reactions with aluminum(III). Wat. Res. 21/11, 1401-1407 (1987).

McDowell, W.H. and Wood, T. Podzolidation: soil processes control dissolved organic carbon concentrations in stream water. Soil Science 137/1 (1984).

Motschi, H. and Rudin, M. ${ }^{27}$ Al ENDOR study of $V o^{2+}$ adsorbed on $\delta$-alumina. Colloid and Polymer Sci. 262, 579 (1984).

Perdue, E.M. Acidic functional groups of humic substances. In: Humic Substances in Soil, Sediment and Water. Aiken, McKnight, Wershaw, MacCarthy (eds.), Wiley, New York,(1985).

Raab, D. Saure Depositionen und die Verlagerung von Aluminium in Böden; Diss. ETH Nr. 8948, Zürich (1989).

Scheffer, F. and Schachtschabel, P. Lehrbuch der Bodenkunde. Ferdinand Enke Verlag, Stuttgart (1979).

Schindler, P.W. and Kamber, H.R. Die Acidität von Silanolgruppen, Helv. Chim. Acta, 51, 1781-1786 (1969).

Schindler, P.W. and Stumm W. The surface chemistry of oxides, hydroxides and oxide minerals. In: W. Stumm, Ed., Aquatic Surface Chemistry, New York, Wiley-Interscience, pp. 83-110 (1987).

Schnoor, J.L. and Stumm W. Acidification of aquatic and terrestrial ecosystems. In: Stumm W. (ed.): Chemical Processes in Lakes. Wiley-Interscience, New York, 331-3388 (1985).

Sigg, L. and Stumm W. The interactions of anions and weak acids with the hydrous goethite $(\alpha-F e O O H)$ surface. Colloids and Surfaces 2, 101-117 (1981).

Stumm W. Chemistry of the Solid-Water Interface - Processes at the Mineral-Water and Particle-Water Interface in Natural Systems. Wiley-Interscience, New York (1992). 
Stumm, W. and Furrer G.The dissolution of oxides and aluminum silicates; examples of surface coordination-controlled kinetics. In: Aquatic Surface Chemistry, W. Stumm, ed., Wiley Interscience, New York 197-219 (1987).

Stumm, W. and Morgan J.J. Aquatic Chemistry, Wiley-Interscience (1981).

Stumm, W. and Wieland E. Dissolution of oxide minerals. Rates depend on surface speciation. In: Stumm W. (ed.) Aquatic Chemical Kinetics, Wiley Interscience, New York (1990).

Stumm, W. and Wollast R. Coordination chemistry of weathering: Kinetics of the surface controlled dissolution of oxide minerals. Reviews of Geophysics 28, 53-69 (1990).

Ulrich, B., Mayer, R., and Khanna, P.K. Deposition von Luftverunreinigungen und ihre Auswirkungen in Waldökosystemen im Solling. Schriften forstl. Fakultät Uni. Göttingen Band 58, 2. Auflage, J.D. Sauerländer's Verlag, Frankfurt a.M. (1979).

Ulrich, B. Natural and anthropogenic components of soil acidification. Z. Pflanzenernähr. Bodenk. 149, 702-717 (1986).

Van Breemen, N.J., Mulder J., and Driscoll C.T. Acidification and alkalinization of soils. Plant and Soil 75, 283-308 (1983). 